\title{
Pfeiffer syndrome
}

INSERM

\section{Source}

INSERM. (1999). Orphanet: an online rare disease and orphan drug data base. Pfeiffer syndrome. ORPHA:710

Pfeiffer syndrome (PS) is a common form of acrocephalosyndactyly (see this term), a group of inherited congenital malformation disorders, characterized by variable degrees of bicoronal craniosynostosis, variable hand and foot malformations and various other associated manifestations. 